\title{
Implementasi Ekstrakurikuler Seni Tari ditinjau dari Peserta Didik dan Orangtua
}

\author{
Ani Vandayanti ${ }^{1}$, Rasiman ${ }^{2}$, Mei Fita Asri Untari ${ }^{3}$ \\ 1,2,3 Jurusan Pendidikan Guru Sekolah Dasar, Fakultas IImu Pendidikan \\ Universitas PGRI Semarang \\ e-mail: Anivandayanti001@gmail.com ${ }^{1}$, rasiman45@gmail.com², \\ meifau2@gmail.com ${ }^{3}$
}

\begin{abstract}
Abstrak
Latar belakang yang mendasari penelitian ini adalah peneliti ingin mengetahui bagaimana implementasi ekstrakurikuler seni tari terhadap tercapainya visi dan misi sekolah yang berhubungan dengan ekstrakurikuler.Rumusan masalah penelitian ini adalah bagaimana implementasi ekstrakurikuler seni tari SDN Ngesrep 02 di tinjau dari peserta didik dan orangtua untuk mencapai visi dan misi sekolah yang berhubungan dengan ekstrakurikuler. Tujuan dalam penelitian ini adalah untuk mendeskripsikan implementasi pembelajaran seni tari dalam kegiatan ekstrakurikuler SDN Ngesrep 02 di tinjau dari peserta didik dan orangtua dalam mencapai visi dan misi sekolah.Penelitian ini menggunakan pendekatan deskriptif kualitatif yang dilakukan dengan menguraikan fakta-fakta atau data-data yang diperoleh dari sumber data.Data dalam penelitian ini diperoleh melalui triangulasi data yaitu observasi, dokumentasi dan wawancara. Hasil wawancara 20 peserta didik dan 15 orangtua menunjukkan bahwa visi dan misi sekolah yang berhubungan dengan ekstrakurikuler seni tari sudah tercapai, melalui ekstrakurikuler seni tari guru dan orangtua sudah melihat bakat yang di miliki peserta didik dan ekstrakurikuler merupakan usaha untuk mengoptimalkan potensi peserta didik di bidang non akademik.
\end{abstract}

Kata Kunci: Ekstrakurikuler, Seni Tari, Visi dan Misi, Peserta didik, Orangtua

\begin{abstract}
The background that underlies this research is that the researcher wants to know how to implement extracurricular dance in achieving the school's vision and mission related to extracurricular activities. The formulation of the research problem is how the implementation of extracurricular dance in SDN Ngesrep 02 was reviewed from students and parents to achieve the school's vision and mission related to extracurricular activities. The purpose of this study was to describe the implementation of dance learning in extracurricular activities at SDN Ngesrep 02 in terms of students and parents in achieving the school's vision and mission. This study uses a qualitative descriptive approach that is carried out by describing the facts or data obtained from data sources. The data in this study were obtained through data triangulation, namely observation, documentation, and interviews. Interviews with 20 students and 15 parents showed that the vision and mission of the school related to extracurricular dance arts have been achieved, through extracurricular dance teachers and parents have seen the talent possessed by students and extracurricular activities as an attempt to optimize the potential of non-students academic.
\end{abstract}

Keywords: Extracurricular, Dance, Vision and Mission, Students, Parents 


\section{Pendahuluan}

Pendidikan merupakan suatu wahana untuk meningkatkan sumber daya manusia yang berbudaya. Undang-undang Republik Indonesia Nomor 20 Tahun 2003 Pasal 4 ayat 3 pendidikan diselenggarakan sebagai suatu proses pembudayaan dan pemberdayaan peserta didik yang berlangsung sepanjang hayat. Undang-undang diatas menyebutkan bahwa pembentukan menjadi warga yang berbudaya merupakan tujuan dari pendidikan nasional di Indonesia.

Pendidikan berfungsi dalam proses transformasi dan transaksi serta transfer sosial budaya. Transformasi budaya berarti pelestarian budaya dengan mewariskan budaya kepada generasi penerus untuk dilestarikan dan dikembangkan.Dengan demikian, generasi muda (anak didik) adalah generasi pewaris sekaligus penerus, sasaran (obyek) sekaligus pelaku (subyek) kebudayaan. Transaksi budaya berarti proses tukar-menukar budaya, saling mendapatkan dan memberi, saling mempengaruhi antar budaya untuk mengembangkan jati diri individu, keluarga, masyarakat, dan bangsanya. Transfer budaya berarti peralihan, penyaluran, pewarisan budaya dari generasi tua kepada generasi muda sebagai generasi pewaris atau penerus(A.Y.Soegeng, 2018: 87). Proses tersebut dapat dilaksanakan di sekolah. Dimana sekolah sebagai lembaga pendidikan merupakan sarana dalam mencapai fungsi pendidikan tersebut.

Di SDN Ngesrep 02 sudah dilaksanakan kegiatan ekstrakurikuler seni tari sebagai salah satu usaha untuk mencapai fungsi pendidikan, dimana ekstrakurikuler ini di ikuti oleh peserta didik kelas $1-\mathrm{VI}$ sebagai salah satu ekstrakulikuler yang dapat di pilih, karena setiap peserta didik di SDN Ngesrep 02 di wajibkan untuk mengikuti salah satu ekstrakulikuler yang di sediakan oleh sekolah. Alasan peserta didik mengikuti ekstrakurikuler seni tari bermacammacam ada yang mengikuti karena saran orang tua, dan ada yang mengikuti karena keinginan dirinya sendiri. Ekstrakurikuler seni tari di SDN Ngesrep 02 ini sudah dilaksanakan sejak Oktober 2016, yang di latih oleh salah satu mahasiswa dari Universitas Negeri Semarang dengan di dampingi oleh salah satu guru yang bertanggung jawab terhadap penerapan ekstrakulikuler seni tari. Biasanya ketika latihan menari siswa dibagi menjadi beberapa kelompok sesuai dengan kelasnya.Pengelompokan ini bertujuan untuk memudahkan pelatih dalam mengajarkan gerakan menari agar sesuai dengan kemampuan siswa.

Menurut Inriyani (2017) kegiatan ekstrakurikuler identik dengan tempat berkumpul para siswa untuk menghilangkan kejenuhanrutinitas belajar di kelas bahkan terkadang para siswa tidak dapat mengatur waktu antara kegiatan di kelas dan kegiatan ekstrakurikuler dari kesibukan mengikuti kegiatan ekstrakurikuler maka kebanyakan waktu siswa tersita karena waktu malam hari biasanya digunakan untuk mengerjakan PR justru digunakan untuk istirahat karena stamina yang menurun. Kegiatan ekstrakurikuler yang diharapkan dapat membantu siswa untuk tumbuh mandiri dalam hal ini dapat mengarahkan serta menumbuhkan minat, bakat dan potensi para siswa yang pada akhirnya akan berprestasi dalam pendidikannya. Suryosubroto (2009: 287) mengatakan bahwa "kegiatan ekstrakurikuler adalah kegiatan tambahandiluarstruktur program yang dilaksanakan di luar jam pelajaran biasa agar memperkaya dan memperluas wawasan pengetahuan dan kemampuan siswa". Menurut Yediya (2014) bagian dari kebudayaan yang menjadi dasar dan wujud dari kebudayaan itu sendiri terkandung dalam nilai budaya, nilai merupakan sesuatu yang dianggap penting dan menjadi bagian dalam proses kehidupan manusia untuk dapat mengatur dan menjaga kualitas pola perilaku yang dilakukan oleh manusia. Menurut Suhaya (2016) seni merupakan istilah yang identik dengan keindahan, kesenangan, dan rekreasi. Saat kita mendengar kata seni maka yang mungkin muncul dalam benak kita adalah suatu karya seni entah berupa benda, music, bangunan, lukisan atau benda-benda indah lainnya yang dihasilkan oleh seorang seniman yang tentunya sangat berbakat dan memiliki kreativitas yang tinggi. Menurut Sustiawati (2017) bidang seni tari merupakan salah satu media berkomunikasi (berekspresi seni) yang memiliki daya tarik bagi anak SD. Menurut Arisyanto (2018) hasil belajar menari mempunyai nilai keuntungan dari hanya sekedar mempertunjukan ketrampilan menari siswa dan ditonton banyak orang. Belajar menari untuk tujuan pendidikan bukanlah untuk menjadi penari atau artis, tetapi lebih bertujuan untuk pembentukan karakter, mengembangkan kreativitas dan multi kecerdasan. Melalui pendidikan seni, berbagai kemampuan dasar manusia seperti fisik, perseptual, pikir, emosional, kreativitas, sosial, dan estetika dapat dikembangkan. Berkreasi seni tari dapat mengembangkan kompetensi dasar motorik halus yang sesuai dengan masa-masa perkembangan yang bersifat polos, unik, kreatif, spontanitas, dan dinamis. Ekstrakulikuler seni tari dilaksanakan pada hari sabtu mulai pukul $10.00-13.00$ setelah 
kegiatan belajar mengajar peserta didik selesai sehingga tidak menganggu pendidikan formal peserta didik. Pembagian waktunya yaitu di mulai dari kelas I dan kelas II, setelah kelas I dan kelas II selesai di lanjutkan dengan kelas III, kelas IV, V dan VI menjadi satu kelompok karena yang mengikuti ekstrkurikuler seni tari dari kelas V dan VI hanya beberapa peserta didik. Setiap kelompok kelas di ajarkan menari yang berbeda-beda.Tari yang diajarkan yaitu tari tradisional dan tari kreasi.

Adapun kendala yang dihadapi terhadap implementasi ekstrakulikuler seni tari di SDN Ngesrep 02 yang di tinjau dari peserta didiik dan orang tua yaitu, dari orang tua lebih pada permasalahan financial (keuangan) karena ketika ada pentas tari atau untuk perlombaan di butuhkan biaya untuk memenuhi kebutuhan peserta didik mulai dari kostum sampai dengan make-up, sedangkan dari pihak sekolah tidak dapat memebantu biaya sepenuhnya karena dana BOS hanya terbatas.Permasalahan dari peserta didik sendiri yaitu kurangnya motivasi peserta didik dalam mengikuti kegiatan ekstrakurikuler seni tari sehingga untuk meningkatkan motivasi dari peserta didik pelatih memberian reward untuk peserta didik yang rajin berangkat dan mengikuti kegiatan ekstrakurikuler tari dengan baik. Adapun dari sekolah akan memberikan nilai tambahan dalam rapor peserta didik di point keaktifan peserta didik.

Tujuan ekstrakurikuler seni tari di SDN Ngesrep 02 antara lain yaitu untuk mengali dan mewadahi potensi dan bakat yang di miliki peserta didik yang berhubungan dengan visi dan misi sekolah, membekali peserta didik dengan ketrampilan. Sekolah memiliki harapan agar peserta didik dapat mengembangkan potensi yang di milikinya sehingga dapat berguna untuk dirinya sendiri dan untuk masyarakat.

Khusus untuk anak yang berbakat, pendidikan seni dapat mengembangkan bakat seni tersebut menjadi seorang seniman, tetapi tidaksetiap peserta didik di didik menjadi seniman.Karena berbagai macam keterampilan yang dimiliki oleh manusia dan kemampuankemampuan lainnya bersifat alamiah atau sudah tertanam dalam otak sejak manusia dilahirkan ke bumi ini (Azzet, 2014: 20). Hal ini menunjukkan bahwa seorang anak manusia yang dilahirkan ke dunia ini sudah dibekali dengan pembawaan, bakat, atau potensi yang sangat penting dalam proses perkembangan berikutnya sejak lahir. Hal tersebut diperkuat dengan pernyataan Safrina (2013: 30) yang menyatakn bahwa bakat yang dimiliki seseorang dipercaya berasal dari pola genetik atau rangkaian DNA yang dibawanya.Oleh karena itu, biasanya bakat menurun dari satu keluarga atau berada dalam satu generasi.

Untuk mencapai tujuan tersebut maka dibutuhkan kerjasama yang baik antara sekolah dan orangtua.Kerjasama yang baik antara orangtua dan sekolah turut menentukan pertumbuhan dan perkembangan anak.Ketika orangtua mendaftarkan anaknya ke suatu sekolah, saat itulah orangtua tersebut memberikan kepercayaan kepada sekolah untuk turut mendidik anaknya.Ketika pihak sekolah memutuskan untuk menerima anak yang bersangkutan sebagai siswa, pada saat itulah sekolah menyatakan kesediaan menerima kepercayaan dari orangtua untuk mendidik anak tersebut.Saat itulah terjadinya kerjasama antara orangtua dan sekolah.Namun bagaimanapun juga, perlu ditegaskan bahwa pendidik pertama dan utama adalah orangtua.Oleh karena itu pihak sekolah perlu melakukan variasi dan diferensiasi dalam melaksanakan kerjasama. Kerjasama sekolah dengan orangtua antara lain dapat dilakukan dengan: (1) menjadikan orangtua sebagai partner dalam pendidikan moral, dan (2) sekolah memfasilitasi orangtua untuk membentuk komunikasi yang mengadakan pertemuan secara rutin dan periodik, dapat mengambil tempat di sekolah maupun di rumah salah satu orangtua siswa.

Penelitian ini nantinya akan membahas tentang bagaimana implementasi ekstrakurikuler di lihat dari sudut pandang dan bagaimana peran orangtua serta bagaimana implementasi ekstrakurikuler di lihat dari sudut pandang peserta didik dan bagaimana peran peserta didik dalam melaksanakan kegiatan seni tari, yang kemudian hasil penelitian akan di analisis setelah mendapatkan data melalui metode pengumpulan data berupa observasi, wawancra dan dokumentasi apakah hasil dari implementasi ekstrakurikuler di tinjau dari orangtua dan peserta didik dapat mencapai visi dan misi sekolah yang berhubungan dengan ekstrakuriukler seni tari.

\section{Metode}

Sumber data dalam penelitian ini adalah subjek darimana data dapat diperoleh. Sumber datadapat diklasifikasikan menjadi tiga (Arikunto. 2014: 172), yaitu: 1. Person

Sumber data person yaitu sumber data yang bias memberikan data berupa jawaban lisan melalui wawancara atau jawaban tertulis melalui angket. Sumber data person yang diperoleh 
dalam penelitian ini adalah peserta didik SDN Ngesrep 02 dan orang tua peserta didik yang mengikuti kegiatan ekstrakurikuler seni tari yang memberikan data berupa jawaban dari wawancara yang pertanyaanya sudah di tentukan peneliti, guru ekstrakurikuler seni tari dan kepala sekolah SDN Ngesrep 02 yang memberikan data berupa jawaban lisan melalui wawancara.

2. Place

Sumber data place yaitu sumber data yang menyajikan tampilan berupa keadaan diam dan bergerak. Sumber data place dalam penelitian ini adalah kegiatan pembelajaran ekstrakurikuler seni tari SDN Ngesrep 02 dan sarana prasarana yang di gunakan untuk ekstrakurikuler seni tari.

3. Paper

Sumber data paper yaitu sumber data yang menyajikan tanda-tanda berupa huruf, angka, gambar, atau simbol-simbol lain. Sumber data yang diperoleh melalui paper dalam penelitian ini adalah nama-nama peserta didik yang mengikuti kegiatan ekstrakurikuler seni tari di SDN Ngesrep 02, nama-nama orang tua peserta didik yang mengikuti kegiatan ekstrakurikuler seni tari, dokumentasi sekolah dan gambar atau foto kegiatan proses belajar mengajar.

Bila dilihat dari sumber datanya, maka pengumpulan data dapat menggunakan sumber primer dan sumber sekunder.

1. Sumber primer

Adalah sumber data yang langsung memberikan data kepada pengumpul data. Sumber primer dalam penelitian ini adalah peserta didik dan orang tua dengan menggunakan wawancara terstruktur sedangkan guru atau pelatih dan kepala sekolah yang memberikan data langsung melalui wawancara tidak terstruktur dengan peneliti.

2. Sumber data sekunder

Merupakan sumber data yang tidak langsung memberikan data kepada pengumpul data, misalnya lewat orang lain atau lewat dokumen. Sumber sekunder dalam penelitian ini adalah dokumentasi tentang pembelajaran seni tari di SDN Ngserep 02. Selanjutnya bila dilihat dari segi cara atau teknik pengumpulan data, maka teknik pengumpulan data dapat dilakukan dengan observasi (pengamatan), interview (wawancara), dokumentasi dan gabungan ketiganya (Sugiyono, 2016: 309). Untuk melengkapi data yang di perlukan oleh peneliti.

Teknik pengumpulan data dalam penelitian ini dilakukan observasi, wawancara dan dokumentasi. Berikut penjelasannya:

a. Observasi (Pengamatan)

Nasution, 1988 (dalam Sugiyono, 2016: 310) menyatakan bahwa observasi adalah dasar semua ilmu pengetahuan. Para ilmuan hanya dapat bekerja berdasarkan data, yaitu fakta mengenai dunia kenyataan yang diperoleh melalui observasi. Sanafiah Faishal, 1990 (dalam Sugiyono, 2016: 310) mengklarifikasikan observasi menjadi observasi partisipatif (participant observation), observasi secara terus terang dan tersamar (overt observation dan covert observation) dan observasi tak berstruktur (unstructured observation). Penelitian ini menggunakan observasi secara terus terang dan tersamar, yaitu peneliti dalam melakukan pengumpulan data menyatakan terus terang kepada sumber data, bahwa ia sedang melakukan penelitian. Tetapi dalam suatu saat peneliti juga tidak terus terang atau tersamar dalam observasi, hal ini untuk menghindari jika suatu saat datayang dicari merupakan data yang masih dirahasikan (Sugiyono, 2016: 312). Observasi ini di laksanakan sebelum penelitian berlangsung.

b. Wawancara

Menurut Esteberg (dalam Sugiyono, 2016: 317) wawancara merupakan pertemuan dua orang untuk bertukar informasi dan ide melalui tanya jawab, sehingga dapat dikontruksikan makna dalam suatu topic tertentu. Ada beberapa macam wawancara yaitu wawancara terstruktur, semiterstruktur dan tidak terstruktur.

Penelitian ini menggunakan wawancara semiterstruktur untuk peserta didik dan orang tua. Dimana wawancara semiterstruktur ini merupakan jenis wawancara yang sudah termasuk dalam kategori in-depth interview, dimana dalam pelaksanaanya lebih bebas bila dibandingkan dengan wawancara tersruktur. Tujuan dari wawancara ini adalah untuk menemukan permasalahan secara lebih terbuka, dimana fihak yang diajak wawancara diminta pendapat, dan ide-idenya.

Dalam melakukan wawancara, peneliti perlu mendengarkan secara teliti dan mencatat apa yang dikemukakan oleh informan. Sedangkan untuk guru dan kepala sekolah peneliti menggunakanwawancara tidak berstruktur.Wawancara tidak berstruktur adalah 
wawancara yang bebas di mana peneliti tidak menggunakan pedoman wawancara yang telah tersusun secara sistematis dan lengkap untuk pengumpulan datanya. Pedoman wawancara yang di gunakan hanya berupa garis-garis besar permasalahan yang akan ditanyakan.

c. Dokumentasi

Dokumen merupakan catatan peristiwa yang sudah berlalu. Dokumen bisa berbentuk tulisan, gambar, atau karya-karya monumental dari seseorang. Dokumen yang berbentuk tulisan misalnya catatan harian, sejarah kehidupan (life histories), ceritera, biografi, peraturan, kebijakan. Dokumen yang berbentuk gambar, misalnya foto, gambar hidup, sketsa dan lain-lain. Studi dokumen merupakan pelengkap dari penggunaan metode metode observasi dan wawancara dalam penelitian kualitatif (Sugiyono, 2016: 329).

\section{Hasil dan Pembahasan}

Berdasarkan deskripsi dan penemuan diatas, pembahasan dalam penelitian ini yaitu Implementasi Ekstrakurikuler Seni Tari SDN Ngesrep 02 di tinjau dari orangtua dan peserta didik.

Berdasarkan Peraturan Menteri Pendidikan Nasional Nomor 19 Tahun 2007 tanggal 23 Mei 2007 mengenai Standar Pengelolaan Pendidikan oleh Satuan Pendidikan Dasar dan Menegah, sekolah harus membuat, merumuskan, dan menetapkan visi, serta mengembangkannya. Visi merupakan cita-cita masa depan yang ada pada pemikiran para warga sekolah yang diharapkan dapat dicapau di masa depan. Visi juga merupakan representasi dari keyakinan mengenai bagaimana seharusnya pendidikan pada satuan tingkat pendidikan di masa depan.

Formula visi yang baik biasanya dengan kalimat atau kata-kata yang ringkas, menarik perhatian, mudah diingat, memberikan inspirasi dan memberikan tantangan prestasi di masa depan, dapat dipercaya, serta konsisten dengan nilai strategis dan pernyataan misi. Visi berfungsi sebagai titik temu dengan stakeholder penting, dapat dengan jelas menyatakan esensi mengenai seperti apa seharusnya pendidikan di suatu lembaga, dan memungkunkan fleksibilitas dan kreativitas dalam pelaksanaannya (Wiranto dalam Teguh, 2015: 106).

Selain penetapan visi, sekolah juga merumuskan, menetapkan, dan mengembangkan misi.Misi dirancang untuk memberikan tuntunan yang kuat dalam pengambilan keputusan manejemen sekolah.Misi merupakan adaptasi ringkas daro sebagian visi yang telah dirumuskan melalui kalimat yang lebih operasional. Pernyataan misi lebih komprehensif dan mencakup konsep lembaga, sifat layanan, alasan keberadaan lembaga, pihak-pihak yang dilayani, serta prinsip dan nilai yang akan menjadi pegangan pada saat menjalankan kegiatan.

Ekstrakurikuler seni tari berhubungan dengan visi dan misi sekolah poin ke 2 dan ke 4 yaitu menyelenggarakan pembelajaran dan bimbingan secara efektif untuk mengoptimalkan potensi akademik dan non akademik yang di miliki oleh peserta didik dan menggali bakat dan minat siswa dengan ekstrakurikuler. Dalam upaya untuk mencapai visi dan misi maka guru ekstrakurikuler membuat rencana kegiatan pembelajaran setiap bulannya yang berisi materimateri dari tari yang di ajarkan.Dalam 1 bulan peserta didik harus menyelesaikan 1 tarian yang sudah termasuk dengan ujian tari yang di ajarkan.

Ekstrakurikuler seni tari di laksanakan setiap seminggu sekali pada hari sabtu di mulai dari pukul 10.00-13.00 setelah peserta didik pulang sekolah sehingga tidak menganggu proses belajar mengajar peserta didik. Hal ini merupakan upaya untuk mencapai visi dan misi sekolah untuk mengoptimalkan potensi non akademik yang di miliki peserta didik karena ekstrakurikuler seni tari termasuk dalam non akademik.

Sebagai upaya untuk mencapai visi dan misi sekolah juga memberikan fasilitas untuk kegiatan ekstrakurikuler seni tari berupa fasilitas fisik yaitu tempat yang di gunakan untuk latihan dan alat elektronik yang mendukung, untuk leptop pelatih/guru membawa sendiri sesuai dengan pernyataan Ibu Haris Harjanti pada 06 Oktober 2018 "Untuk leptop membawa sendiri kerana semua video dan lagu yang di gunakan untuk ekstrakurikuler seni tari ada di leptop milik saya sendiri. Jadi akan lebih mudah jika membawa leptop sendiri. Untuk jarik, sampur, dll yang membawa peserta didik sendiri". Untuk fasilitas uang sekolah di bantu oleh orangtua peserta didik untuk memenuhi kebutuhan ekstrakurikuler seni tari.

Selain memberikan fasilitas untuk kegiatan ekstrakurikuler seni tari, adapun faktor pendukung untuk mencapai visi dan misi sekolah seperti keberhasilan peserta didik putri dalam lomba Jambore tingkat Kecamatan Banyumanik 2018 di Lapangan SMA 04 Semarang yang berhasil memdapat juara II. Untuk menunjukkan eksistensi SDN Ngesrep 02 dalam menari kegiatan pentas lain yang sudah di ikuti yaitu FL2N tingkat Kecamatan Banyumanik 2017, FL2N 
tingkat Kecamatan Banyumanik 2018, Pesta Siaga tingkat Kecamatan Banyumani tahun 2018, Hari Tari Dunia di Universitas Negerri Semarang, Pelepasan Siswa kelas 6 SDN Ngesrep 02, FL2N tingkat Kecamatan Banyumanik tahun 2019, dan Pesta siaga tingkat Kecamatan Banyumanik tahun 2019. Keikutsertaan peserta didik dalam lomba-lomba tersebut merupakan bentuk dari eksistensi sekolah dan dapat untuk menambah pengalaman peserta didik serta pembuktian hasil dari mengikuti ekstrakurikuler seni tari.

Berdasarkan analisis di atas berikut adalah hasil rakap wawancara peserta didik dan orangtua tentang implementasi ekstrakurikuler seni tari yang ada di SDN Ngesrep 02.

Dari hasil rekap wawancara kepada 20 peserta didik ditemukan beberapa masalah antara lain masih banyaknya peserta didik yang belum mendapatkan kesempatan untuk pentas tari di sekolah maupun di luar sekolah. Ini di sebabkan karena minimnya pementasan tari di tunjukkan dari lomba-lomba dan pementasan yang sudah di ikuti peserta didik dalam kurun waktu setahun peserta didik hanya mendapat kesempatan tampil untuk pentas atau lomba 1-3 kali saja. Walau begitu guru dan sekolah juga terus berusaha untuk mengikutkan peserta didik pentas di sekolah mauoun di luar sekolah yang memungkinkan untuk di ikuti.

Untuk pentas di dalam sekolah, guru tari dan sekolah berusaha selalu menampilkan peserta didik yang di tunjuk untuk mengisi acara perpisahan kelas $\mathrm{VI}$, walaupun belum semua peserta didik yang dapat pentas setidaknya ini bisa menjadi motivasi untuk peserta didik belajar menari dan melatih rasa percaya diri peserta didik.

Peserta didik memiliki hak dan kewajiban yang harus di laksanakan.Dengan adanya ekstrakurikuler ini peserta didik sudah mendapatkan salah satu haknya yaitu hak mendapatkan pelayanan pendidikan sesuai dengan bakat, minat, dan kemampuannya karena ekstrakurikuler seni tari memang di tujukan untuk peserta didik yang memiliki bakat dan minat untuk dapat di kembangkan. Maka dari itu peserta didik juga harus menjalankan kewajibannya yaitu belajar dengan cara rajin berangkat ekstrakurikuler. Hal ini sudah di tunjukkna kepada peserta didik SDN Ngesrep 02 yang rajin mengikuti ekstrakurikuler walaupun masih ada yang terkadang malas berangkat.

Permasalahan beberapa peserta didik yang malas berangkat ekstrakurikuler seni tari karena hanya sedikit temannya yang berangkat. Ini di alami oleh peserta didik kelas III dan V, karena dari kelas III dan kelas V yang mengikuti ekstrakurikuler seni tari hanya beberapa peserta didik saja jadi peserta didik sering merasa malas berangkat dan berdampak pembelajaran mengalami keterlambatan. Yang seharusnya ketika berangkat semua bisa berlatih gerakan baru ketika yang berangkat hanya sedikit atau tidak ada yang berangkat maka di pertemuan selanjutnya pelatih/guru harus mengulang gerakan baru yang akan di ajarkan. Untuk mengatasi permasalahan ini pelatih/guru biasanya mengabungkan kelas III dengan kelas II atau kelas IV di sesuaikan dengan tari yang akan di ajarkan. Sedangkan kelas V di gabung dengan kelas IV atau kelas VI agar pembelajaran tetap berlangsung dengan semestinya.

Walaupun masih ada beberapa masalah yang di alami pada pelaksanaan ekstrakurikuler seni tari namun itu tidak menghalangi untuk mencapai visi dan misi sekolah.Masih banyak faktor yang mendukung untuk mewujudkan visi dan misi sekolah.Seperti banyak peserta didik yang mengikuti ekstrakurikuler seni tari karena suka menari, dari sini orangtua maupun guru dapat melihat bakat peserta didik melalui minatnya mengikuti ekstrakurikuler seni tari yang di ikuti.Selain itu ekstrakurikuler seni tari dapat mengoptimalkan waktu luang peserta didik dengan kegiatan non akademik yang positif setelah pulang sekolah yang tentunya tidak menganggu waktu belajar peserta didik.

Peserta didik merupakan insan yang memiliki aneka kebutuhan.Kebutuhan itu terus tumbuh dan berkembang sesuai dengan sifat dan karakteristiknya sebagai manusia. Kebutuhan itu antara lain sebagai berikut kebutuhan intelektual, sosial, fisik, emosional, moral dan homodivinous. Melalui ekstrakurikuler seni tari kebutuhan peserta didik yang dapat di penuhi yaitu kebutuhan intelektual, melalui ekstrakurikuler seni tari peserta didik menjadi tahu tentang berbagai tarian yang ada di Indonesia dan bagaimana gerakan-gerakan yang ada di setiap tarian.Kebutuhan sosial, melalui ekstrakurikuler seni tari peserta didik dapat berinteraksi dengan teman sebayanya dan guru tari untuk memenuhi kebutuhan sosialnya.Kebutuhan fisik, gerak tari melibatkan aktivitas fisik dimana melalui gerak peserta didik dapat belajar keterampilan motorik halus dan juga kasar seperti melompat, meloncat, berjingkrak dan berlari yang ada dalam gerakan menari.Dan kebutuhan homodivinous, yang di tunjukkan ketika berdoa sebelum kegiatan ekstrakurikuler di mulai dan setelah kegiatan ekstrakurikuler selesai.

Dengan peserta didik mengikuti ekstrakurikuler seni tari, peserta didik dapat belajar taritarian yang ada di Indonesia seperti tari tradisional yaitu tari golek, denok, merak, dll dan tari kreasi yaitu tari lilin, lenggang nyai, babalu, tor-tor, gembira, indang, jaranan, burung enggang, 
dll. Tari yang di ajarkan kebanyakan tari kreasi karena peserta didik lebih suka di ajarkan tari kreasi daripada tari tradisional.Menurut peserta didik karena lebih mudah tari kreasi daripada tari tradisional.Walau begitu guru tetap mengajari beberapa tari tradisonal untuk peserta didik agar peserta didik dapat mengenal beberapa tari tradisional yang ada di Indonesia.

Dalam ekstrakurikuler seni tari peserta didik di ajarkan berbagai tarian yang ada di Indonesia, dengan menari inilah bakat yang di miliki peserta didik dapat tergali dan di kembangkan. Melalui latihan menari dengan gerakan di setiap tarian yang berbeda-beda dan di lakukan terus-menerus secara rutin maka bakat yang di miliki peserta didik akan terasah sehingga di harapkan bakat yang di miliki peserta didik ini bisa menjadi keungulang yang di miliki peserta didik agar dapat berguna untuk dirinya dan orang lain di masa kini maupun masa depan. Hal ini sesuai dengan pernyataan dari Ibu Mudrikah pada 04 Oktober 2018 "Tujuan di selenggarakan kegiatan ekstrakurikuler seni tari yaitu untuk menggali dan mewadahi potensi dan bakat yang di miliki peserta didik, membekali peserta didik dengan keterampilan yang di harapkan berguna untuk masa depan peserta didik dan sebagai upaya mewujudkan visi dan misi sekolah yang berhubungan dengan ekstrakurikuler".

Adapun tujuan pelaksanaan ekstrakurikuler menurut Suryosubroto (2009: 287) sudah tercapai dalam pelaksanaan ekstrakurikuler seni tari yaitu kegiatan ekstrakurikuler harus dapat meningkatkan kemampuan siswa dalam aspek kognitif yang di tunjukkan oleh peserta didik yang mengetahui berbagai tarian yang ada di Indonesia setelah mengikuti ekstrakurikuler seni tari, aspek afektif berhubungan dengan sikap peserta didik saat mengikuti ekstrakurikuler seni tari yang sudah baik dan memperhatikan ketika latihan dan berani bertanya ketika mengalami kesulitan, aspek psikomotor di tunjukkan dari keterampilan peserta didik dalam membawakan gerakan yang ada di dalam tarian yang di ajarkan. Kegiatan ekstrakurikuler juga bertujuan untuk mengembangkan bakat dan minat siswa dalam upaya pembinaan pribadi menuju pembinaan manusia seutuhnya yang positif dan ini sudah tercapai dengan sudah terlihatnya bakat menari yang di miliki peserta didik.

Dari rekap hasil wawancara kepada 15 orangtua di temukan beberapa permasalahan yang terjadi seperti permasalahan financial yang terjadi ketika peserta didik akan pentas namun orangtua harus mengeluarkan dana pribadi untuk memenuhi kebutuhan. Ini menjadi permasalahan karena perekonomian setiap orangtua berbeda-beda jadi agar dana yang di keluargakan orangtua tidak begitu banyak dan mengingat bahwa peserta didik pentas mewakili sekolah maka sekolah membantu meringankan biaya dengan menanggung biaya untuk transportasi. Sekolahpun tidak bisa banyak membantu mengenai permasalahan dana karena dana yang di miliki sekolah bukan hanya di gunakan untuk kebutuhan ekstrakurikuler seni tari saja namun untuk kegiatan yang lainnya juga. Walau begitu orangtua tetap memenuhi biaya yang sudah di anggarkan sekolah karena orangtua juga menyadari bahwa itu untuk kepentingan bersama dan sudah menjadi tugas orangtua dalam memenuhi kebutuhan peserta didik dalam pendidikannya. Hal ini sesuai dengan pernyataan Ibu Mudrikah "Permasalahan yang timbul dari orangtua yaitu permasalahan financial, orangtua harus mengeluarkan dana pribadi untuk membantu sekolah memenuhi kebutuhan peserta didik yang akan pentas menari. Karena dana yang di miliki sekolah bukan hanya untuk kegiatan ekstrakurikuler saja, jadi sekolah membutuhkan kerjasama dengan orangtua peserta didik. Sekolah hanya bisa membantu untuk kebutuhan transportasi dan untuk kebutuhan yang lain seperti kostum dan make-up di tanggung orangtua peserta didik yang akan ikut pentas. Namun sekolah sudah menganggarkan dana yang di keluarkan oleh orangtua seminim mungkin sehingga orangtua mampu untuk membayar".

Masalah lain yaitu belum tersedianya tempat khusus untuk ekstrakurikuler seni tari, selama ini masih menggunakan ruangan serba guna, ruang serba guna ini di gunakan untuk kegiatan ekstrakurikuler komputer, rebana dan seni tari. Hal ini menyebabkan peserta didik terkadang harus berganti tempat di ruang kelas ketika jam ekstrakurikuler satu dan yang lainnya bersamaan sehingga pembelajaran tidak maksimal. Sebagai upaya sekolah dalam usahanya mencapai visi dan misi, sekolah menyediakan ruang kelas dan halaman sekolah sebagai ruang ekstrakurikuler seni tari apabila ruangan yang di gunakan untuk ekstrakurikuler seni tari di pakai untuk kegiatan ekstrakurikuler lainnya.

Walaupun masih ada beberapa permasalahan yang terjadi dalam implementasi ekstrakurikuler seni tari namun hal itu tidak menjadi hambatan sekolah untuk tetap mencapai visi dan misi yang sudah ada.Masih ada banyak faktor pendukung agar visi dan misi sekolah dapat tercapai.Seperti aspek-aspek dukungan orangtua untuk peserta didik yang mengikuti ekstrakurikuler seni tari seperti aspek dukungan emosional yang di tunjukkan orangtua terhadap peserta didik melalui pemberian motivasi, mengingatkan peserta didik kapan 
berangkat ekstrakurikuler, memberikan support, semangat, dll.Aspek dukungan penghargaan yang di tunjukkan oleh orangtua dengan memberikan izin peserta didik untuk mengikuti ekstrakurikuler seni tari.Aspek dukungan instrumental dengan memenuhi kebutuhan peserta didik yang di perlukan termasuk mengeluargan dan pribadi untuk keperluan pentas atau lomba yang berhubungan dengan menari.Dan aspek dukungan informasi yang di tunjukkan melalui mengarahkan dan menyarankan peserta didik untuk mengikuti ekstrakurikuler dengan berbagai macam alasan yang positif. Dukungan dari orangtua sangat penting bagi sekolah dan pesrta didik karena untuk kesuksesan program sekolah membutuhkan dukungan dari orangtua dan komunikasi yang baik antara peserta didik, orangtua dan sekolah agar bisa berjalan dengan tujuan yang sama yaitu mencapai visi dan misi sekolah.

Melalui ekstrakurikuler seni tari orangtua sudah menjalankan kewajibannya yaitu mendidik dan berbagi ilmu karena melalui ektstrakurikuler seni tari peserta didik dapat belajar berbagai tarian yang ada di Indonesia, belajar melestarikan kebudayaan dan mencintai budaya bangsa sendiri melalui seni tari, menambah pengalaman dengan mengikuti pentas tari, dan lainnya yang di harapkan dapat berguna di kemudian hari, ekstrakurikuler seni tari juga membawa dampak yang positif seperti orangtua menjadi tahu bakat yang di miliki peserta didik, selain itu peserta didik bisa memanfaatkan waktu luangnya dengan kegiatan yang positif,

Dari deskripsi di atas penemuan hasil observasi, wawancara peserta didik, orangtua, guru ekstrakurikuler dan kepala sekolah terhadap Impementasi ekstrakurikuler seni tari di tunjau dari peserta didik dan orangtua telah sesuai dengan hasil wawancara peserta didik dan oranngtua.Di tunjukkan dari hasil rekab wawancara kepada 20 peserta didik dan 15 orangtua tentang implementasi ekstrakurikuler seni tari.Walaupun terdapat beberapa masalah namun tidak menjadi hambatan untuk mencapai visi dan misi yang ada.

Untuk visi dan misi yang berhubungan dengan ekstrakurikuler seni tari sudah tercapai seperti apa yang di katakan oleh Ibu Mudrika pada 02 Mei 2019 "Tujuan di laksanakannya ekstrakurikuler salah satunya adalah untuk menggali bakat dan minat siswa, ini berhubungan dengan visi dan misi nomer 2 dan 4 mbak. Di adakannya ekstrakurikuler salah satunya ekstrakurikuler seni tari itu adalah bentuk dari usaha mencapai visi dan misi, dan alhamdulillah untuk ekstrakurikuler seni tari itu sudah tercapai ya mbak terlihat dari anak-anak yang mengikuti ekstra sudah mulai terlihat bakat-bakat yang di miliki anak. Sekolah berusaha mewadahi dan mengembangkan bakat yang di milik anak ya semoga saja itu akan berguna bagi sekolah dan masa depan anak. Ekstrakurikuler ini juga termasuk pengoptimalan potensi anak di bidang non akademik". Tercapainya visi dan misi peserta didik dalam hal bakat dan minat di perkuat dengan pernyataan dari Ibu Janti selaku guru ekstrakurikuler seni tari pada 02 Mei "Kalau bakat memang sudah ada yang terlihat, biasanya anak yang memang ada bakat itu kalau nari kelihatan luwes, cepet juga menghafal gerakannya, terus juga ketukan tari sama lagunya itu bisa pas gitu bisa sesuai dan ini sudah di perlihatkan oleh anak-anak walaupun tidak semua anak". Jadi dapat di simpulkan bahwa visi dan misi SDN Ngesrep 02 yang berhubungan dengan ekstrakurikuler seni tari sudah tercapai.

\section{Simpulan dan Saran}

Berdasarkan hasil pembahasan pada bab sebelumnya, maka dapat disimpulkan sebagai berikut, pembelajaran ekstrakurikuler seni tari di SDN Ngesrep 02 sudah dilaksanakan selama dua tahun sebagai salah satu ekstrakurikuler yang ada di SDN Ngesrep 02. Dari hasil wawancara terhadap 20 peserta didik ditemukan beberapa masalah antara lain masih banyaknya peserta didik yang belum mendapatkan kesempatan untuk pentas tari di sekolah maupun di luar sekolah, masih ada beberapa peserta didik yang malas berangkat ekstrakurikuler seni tari karena hanya sedikit temannya yang berangkat. Walaupun masih ada beberapa masalah yang di alami pada pelaksanaan ekstrakurikuler seni tari namun itu tidak menghalangi untuk mencapai visi dan misi sekolah.Masih banyak faktor yang mendukung untuk mewujudkan visi dan misi sekolah.Seperti banyak peserta didik yang mengikuti ekstrakurikuler seni tari karena suka menari.Selain itu ekstrakurikuler seni tari dapat mengoptimalkan waktu luang peserta didik dengan kegiatan non akademik yang positif setelah pulang sekolah yang tentunya tidak menganggu waktu belajar peserta didik. Dari hasil wawancara terhadap 15 orangtua di temukan beberapa permasalahan yang terjadi seperti permasalahan financial, masalah lain yaitu belum tersedianya tempat khusus untuk ekstrakurikuler seni tari, selama ini masih menggunakan ruangan serba guna. Walaupun masih ada beberapa permasalahan yang terjadi dalam implementasi ekstrakurikuler seni tari namun hal itu tidak menjadi hambatan sekolah untuk tetap mencapai visi dan misi yang sudah 
ada.Masih ada banyak faktor pendukung agar visi dan misi sekolah dapat tercapai.Seperti aspek-aspek dukungan orangtua yang sudah diberikan untuk peserta didik yang mengikuti ekstrakurikuler seni. Dukungan dari orangtua sangat penting bagi sekolah dan pesrta didik karena untuk kesuksesan program sekolah membutuhkan dukungan dari orangtua dan komunikasi yang baik antara peserta didik, orangtua dan sekolah agar bisa berjalan dengan tujuan yang sama yaitu mencapai visi dan misi sekolah. Ekstrakurikuler seni tari juga membawa dampak yang positif seperti orangtua menjadi tahu bakat yang di miliki peserta didik, selain itu peserta didik bisa memanfaatkan waktu luangnya dengan kegiatan yang positif, Jadi dari hasil wawancara peserta didik dan orangtua dapat di simpulkan bahwa visi dan misi SDN Ngesrep 02 yang berhubungan dengan ekstrakurikuler seni tari sudah tercapai.

Saran yang berkaitan dengan hasil penelitian implementasi ekstrakurikuler seni tari di tinjau dari peserta didik dan orangtua yaitu bagi pihak sekolah supaya menyediakan tempat khusus untuk pelaksanaan ekstrakuirkuler seni tari sehingga tidak harus bergantian tempat dengan ekstrakurikuler lainnya.Untuk peserta didik ikutilah ekstrakurikuler yang ada di sekolah sesuai dengan minat sehingga ketika pelaksanaan ekstrakurikuler bisa di lakukan dengan senang hati dan dapat bermanfaat karena keinginan diri sendiri.Bagi orangtua, orangtua harus menyadari bahwa kelebihan setiap anak itu berbeda-beda jadi jangan terlalu menuntut anak agar menjadi seperti apa yang di inginkan orangtua. Orangtua perlu mendukung dan mengarahkan apa yang menjadi bakat anak sehingga bakat itu bisa berguna.

\section{Daftar Pustaka}

Arikunto, Suharsimi. 2013. Prosedur Penelitian Suatu Pendekatan Praktik. Jakarta: PT Rineka Cipta.

Arisyanto, Prasena, Riris Setyo Sundari, Mei Fita Asri Untari. 2018. Pembelajaran Ekstrakurikuler Tari untuk Penanaman Karakter bagi Siswa SD Negeri Gayamsari 02 Semarang. Jurnal Pendidikan dan Kajian Seni Vol. 3 No. 1 Hal. 1-13. http://jurnal.untirta.ac.id/index.php/JPKS/article/view/4062. Diakses 10 November 2018.

Azzet, Akhmad Muhaimin. 2014. Mengembangkan Kecerdasan Sosial bagi Anak. Jogjakarta: Katahati.

Danim, Sudarwan. 2013. Perkembangan Peserta Didik. Bandung: ALFABETA, cv.

Inriyani, Yayan Wahjoedi, Sudarmiatin. 2017. Pengaruh Kegiatan Ekstrakurikuler terhadap Prestasi Belajar IPS melalui Motivasi Belajar. Jurnal Pendidikan, Vol. 2, No. 7 Hal. 955962. http://journal.um.ac.id/index.php/jptpp/. Diakses 10 November 2018.

Jazuli, M. 2016. Peta Dunia Seni Tari. Sukoharjo: CV. Farishma Indonesia.

Marini, Arita.2014. Manajemen Sekolah Dasar. Bandung: PT Remaja Rosdakarya.

Nugraheni, Edlin Yanuar. 2015. Mengenal Gerak Tari Dasar Anak. Yogyakarta: Diendra Kreatif.

Rachmi, Tetty.2018. Keterampilan Musik dan Tari. Tangerang Selatan: Universitas Terbuka.

Safrina, Andin. 2013. Deteksi Minat Bakat Anak. Yogyakarta: Media Pressindo.

Sinambela, Pardomuan Nauli. 2017. Kurikulum 2013 dan Implementasinya dalam Pembelajaran. Jurnal Generasi Kampus. https://jurnal.unimed.ac.id/ 2012/index.php/gk/article/view/7085. Diakses 10 November 2018.

Soegeng.A.Y. 2009.Pengantar IImu Pendidikan. Semarang: FIP IKIP PGRI SEMARANG.

Soegeng.A.Y. 2015.Etika Pancasila. Yogyakarta: Magnum Pustaka Utama.

Soegeng.A.Y. 2018. Filsafat Pendidikan. Yogyakarta: Magnum Pustaka Utama. 
Suhaya. 2016. Pendidikan Seni sebagai Penunjang Kreatifitas. Jurnal Pendidikan dan Kajian Seni Vol.1, No.1, Hal. 1-15. http://jurnal.untirta.ac.id/index.php/JPKS/article/viewFile/837/655. Diakses 10 November 2018.

Sugiyono. 2016. Metode Penelitian Pendidikan Pendekatan Kuantitatif, Kualitatif, dan R\&D. Bandung: Alfabeta.

Suryosubroto, B. 2009.Proses Belajar Mengajar. Jakarta: PT Rineka Cipta.

Sustiawati, Ni Luh, Ni Ketut Suryatini, dan Anak Agung Ayu Mayun Artati. 2017. Pengembangan Desain Pembelajaran Seni Tari di Sekolah Dasar Berbasis Localgenius Knowledge Berpendekatan Integrated Learning. MUDRA Jurnal Seni Budaya Volume 32, Nomor 1 Hal. 197-208. https://media.neliti.com/media/publications/195192-ID. Diakses 10 November 2018.

Suwarno, Wiji. 2009. Dasar-dasar IImu Pendidikan. Jogjakarta: AR-RUZZ MEDIA.

Yediya Langoday Hieronimus Aldo. 2014. Peran Pagelaran Seni Tari Kuda Lumping sebagai Media Komunikasi Budaya dalam Melestarikan Nilai Budaya Tradisional (Studi Pada Pagelaran Seni Tari Karyo Mudho Di Kota Samarinda). eJournal Ilmu Komunikasi Vol. 1 No. 2 Hal. 378-387. https://ejournal.ilkom.fisip-unmul.ac.id/site/wpcontent/uploads/2014/03/. Diakses 10 November 2018. 